\title{
DIGLOSIA
}

Volume 1, Nomor 1 (Februari 2018)

\section{PENGEMBANGAN BAHAN AJAR MENULIS CERPEN DENGAN MEDIA STORYBOARD PADA SISWA KELAS X SMA}

\author{
Umi Khulsum ${ }^{1, *}$, Yusak Hudiyono ${ }^{2}$, dan Endang Dwi Sulistyowati ${ }^{3}$ \\ 1,2,3 Magister Pendidikan Bahasa Indonesia, \\ Fakultas Keguruan dan Ilmu Pendidikan, Universitas Mulawarman \\ 1,* Pos-el korespondensi: umikhulsum369@yahoo.co.id \\ ${ }^{2}$ Pos-el: yusak.hudiyono@fkip.unmul.ac.id \\ ${ }^{3}$ Pos-el: endangdwisuliostyowati@yahoo.co.id
}

\begin{abstract}
This study was conducted with the aims of (1) developing teaching materials to write short with storyboard media on high school students; (2) make a lesson plan of writing short story with storyboard media at grade $X$ of high school students; (3) implementation of writing short story with storyboard media at rade X of high school students; (4) knowing the effectiveness of teaching materials in writing short story by using storyboard media at grade X of high school students. This study need a development research method adapted from the Borg and Gall development model with 10 stages beginning with needs analysis, planning, initial product development, initial product revision, product trial, product revision, small field trial, revision product, operational field test (large group), final product revision, and product dissemination and implementation. Based on the data analysis, it was concluded that the teaching materials to write short story with the developed storyboard media was considered feasible and effective to be used as teaching materials for Bahasa Indonesia at Grade X of high school students.
\end{abstract}

Keywords: teaching materials, write short story, storyboard media

\begin{abstract}
ABSTRAK
Penelitian ini dilakukan dengan tujuan: (1) mengembangkan bahan ajar menulis cerpen dengan media storyboard pada siswa kelas X SMA, (2) membuat perencanaan pembelajaran menulis cerpen dengan media storyboard pada siswa kelas X SMA; (3) pelaksanaan pembelajaran menulis cerpen dengan media storyboard pada siswa kelas X SMA; (4) mengetahui keefektifan bahan ajar menulis cerpen dengan media storyboard pada siswa kelas X SMA. Penelitian ini menggunakan metode penelitian pengembangan yang diadaptasi dari model pengembangan Borg \& Gall dengan 10 tahapan yang diawali dengan analisis kebutuhan, perencanaan, pengembangan produk awal, revisi produk awal, uji coba produk, revisi produk, uji coba lapangan utama (kelompok kecil), revisi produk, uji lapangan operasional (kelompok besar), revisi produk akhir, dan diseminasi dan implementasi produk. Berdasarkan analisis data, disimpulkan bahwa bahan ajar menulis cerpen dengan media storyboard yang dikembangkan dinyatakan layak dan efektif digunakan sebagai bahan ajar bahasa Indonesia kelas X SMA.
\end{abstract}

Kata kunci: bahan ajar, menulis cerpen, media storyboard 


\section{A. PENDAHULUAN}

Pendidikan merupakan hal yang tidak dapat dipisahkan dari kehidupan. Pendidikan memegang peranan penting dalam proses meningkatkan kualitas sumber daya manusia karena pendidikan merupakan suatu proses kehidupan dalam mengembangkan diri agar dapat menciptakan sumber daya manusia yang berkualitas yang akan memberikan pengaruh terhadap kemajuan pembangunan bangsa. Adapun tujuan pendidikan nasional yang tercantum dalam UU Sisdiknas No. 20 Tahun 2003 dikatakan bahwa pendidikan nasional bertujuan untuk berkembangnya potensi peserta didik agar menjadi manusia yang bertakwa kepada Tuhan Yang Maha Esa, berakhlak, sehat, berilmu, cakap, kreatif, mandiri, dan menjadi warga negara yang demokratis, serta bertanggung jawab. Dengan dasar tujuan nasional tersebut, setiap unit atau organisasi yang bergerak dalam bidang pendidikan dalam menjabarkan kegiatannya mengacu pada tujuan pendidikan nasional.

Dalam mewujudkan tujuan pendidikan nasional, maka pemerintah telah mengatur sebuah kebijakan agar pendidikan dapat berjalan lebih efektif dan efisien, yaitu dengan mengembangkan kurikulum yang mengacu pada Permendiknas No. 23 Tahun 2006 yang menyebutkan bahwa standar kompetensi lulusan (SKL) satuan pendidikan dikembangkan berdasarkan tujuan setiap satuan pendidikan. Adapun salah satu standar kompetensi lulusan satuan pendidikan SMA/MA adalah mengungkapkan pengalaman diri sendiri dan orang lain ke dalam cerpen. Hal ini menegaskan bahwa pentingnya peserta didik dalam belajar bahasa Indonesia agar memiliki keterampilan berbahasa.

Bahan ajar merupakan salah satu aspek penting dalam dunia pendidikan karena bahan ajar merupakan salah satu sarana untuk mendukung berjalannya proses belajar. Widodo dan Jasmadi (dalam Lestari, 2013:1) menjelaskan bahwa bahan ajar adalah seperangkat sarana atau alat pembelajaran yang berisikan materi pembelajaran, metode, batasan-batasan, dan cara mengevaluasi yang didesain secara sistematis dan menarik dalam rangka mencapai tujuan yang diharapkan, yaitu mencapai kompetensi dan subkompetensi dengan segala kompleksitasnya.

Prastowo (2015:5) mengemukakan bahwa kompetensi profesional yang wajib dimiliki seorang guru di antaranya adalah "Mengembangkan kurikulum yang terkait dengan bidang pengembangan yang diampu dan menyelenggarakan kegiatan pengembangan yang mendidik untuk kompetensi pedagogis serta mengembangkan materi pembelajaran yang diampu secara kreatif'. Dari tuntutan-tuntutan sekaligus kewajibankewajiban ini, guru dituntut untuk mampu menyusun bahan ajar yang inovatif (bisa berwujud bahan ajar cetak, model atau maket, bahan ajar audio, bahan audio visual, atau bahan ajar interaktif).yang sesuai dengan kurikulum, perkembangan kebutuhan peserta didik, maupun perkembangan teknologi informasi.

Penelitian yang dilakukan adalah tentang pengembangan bahan ajar menulis cerpen dengan media storyboard pada siswa kelas X SMA. Tujuan dari penelitian yang dilakukan adalah (1) mengembangkan bahan ajar menulis cerpen dengan media storyboard pada siswa kelas X SMA, (2) membuat perencanaan pembelajaran menulis cerpen dengan media storyboard pada siswa kelas X SMA; (3) pelaksanaan pembelajaran menulis cerpen dengan media storyboard pada siswa kelas X SMA; (4) mengetahui keefektifan bahan ajar menulis cerpen dengan media storyboard pada siswa kelas X SMA.

Sebelum dilakukan penelitian dan pengembangan ini, telah dilakukan 
penelitian terdahulu yang relevan dengan penelitian dan pengembangan ini. Penelitian tersebut di antaranya, penelitian dan pengembangan yang dilakukan oleh Baharudin Adnan tahun 2013 dalam laporan tesisnya yang berjudul Peningkatan Keterampilan Menulis Cerpen Melalui Teknik Papan Cerita (Storyboard) Siswa Kelas X.1 SMA Negeri 1 Minggir, Sleman Yogyakarta. Penelitian ini bertujuan untuk meningkatkan kualitas pembelajaran menulis cerpen siswa kelas X.1 di SMA Negeri 1 Minggir dengan menggunakan model papan cerita (storyboard). Hasil penelitian Adnan tersebut menunjukkan bahwa pembelajaran menulis cerpen menggunakan model papan cerita dapat meningkatkan kualitas dan kuantitas pembelajaran menulis cerpen pada subjek tersebut. Penelitian ini relevan dengan penelitian yang akan penulis teliti. Relevansinya terletak model yang digunakan dalam penelitian tersebut.

\section{B. LANDASAN TEORI \\ 1. Pengertian Bahan Ajar}

Menurut Hamdani (2010:120)

bahan ajar merupakan segala bentuk bahan atau materi yang disusun secara sistematis yang digunakan untuk membantu guru atau instruktur dalam melaksanakan kegiatan belajar mengajar sehingga tercipta lingkungan atau suasana yang memungkinkan siswa untuk belajar. Prastowo (2011:16) mengemukakan bahwa bahan ajar adalah seperangkat materi yang disusun secara sistematis, baik tertulis maupun tidak tertulis sehingga tercipta lingkungan atau suasana yang memungkinkan peserta didik untuk belajar.

Pandangan tersebut juga dilengkapi oleh Pannen (dalam Prastowo, 2016:17) yang mengungkapkan bahwa bahan ajar adalah bahan-bahan atau materi pelajaran yang disusun secara sistematis, yang digunakan guru dan peserta didik dalam proses pembelajaran. Bahan ajar tidak saja memuat materi tentang pengetahuan tetapi juga berisi tentang keterampilan dan sikap yang perlu dipelajari siswa untuk mencapai standar yang telah ditentukan pemerintah. Direktorat Pembinaan Sekolah Atas (Depdiknas, 2008:6) mengemukakan bahwa bahan ajar adalah segala bentuk bahan yang digunakan untuk membantu guru dalam melaksanakan kegiatan belajar mengajar. Bahan yang dimaksud bisa berupa bahan tertulis dan bahan tidak tertulis. Dari beberapa pandangan mengenai pengertian bahan ajar tersebut, dapat dipahami bahwa bahan ajar merupakan komponen pembelajaran yang digunakan oleh guru sebagai bahan belajar bagi siswa dan membantu guru dalam melaksanakan kegiatan belajar mengajar di kelas.

Berdasarkan pengertian-pengertian tersebut di atas, peneliti berpandangan bahwa bahan ajar merupakan seperangkat bahan yang dirancang oleh guru dalam kegiatan pembelajaran guna menunjang kegiatan belajar siswa dalam mencapai kompetensi dasar yang diharapkan. Seperangkat bahan tersebut berupa buku dan sejenisnya, atau program audio, video, serta program komputer yang berisi materi pelajaran. Perancangan bahan ajar harus dirancang secara sistematis oleh guru karena guru sebagai pelaksana dalam kegiatan pembelajaran. Kesistematisan bahan ajar dapat ditunjukkan dengan adanya keterkaitan bahan ajar dengan standar kompetensi, kompetensi dasar yang akan dicapai, indikator pembelajaran, penyusunan bahan ajar juga harus disesuaikan dengan perencanaan pembelajaran dan kebutuhan atau karakteristik peserta didik.

\section{Jenis-Jenis Bahan Ajar}

Ada beberapa bentuk bahan ajar menurut Direktorat Pembinaan Sekolah Atas (Depdiknas, 2008:11). Berdasarkan teknologi yang digunakan, bahan ajar dapat dikelompokkan menjadi empat kategori, yaitu bahan ajar cetak (printed) 
seperti handout, buku, modul, lembar kerja siswa, brosur, leaflet, wallchart, foto/gambar, model/maket. Bahan ajar dengar (audio) seperti kaset, radio, piringan hitam, dan compact disk audio. Bahan ajar pandang dengar (audio visual) seperti video compact disk, film. Bahan ajar multi media interaktif (interactive teaching material) seperti CAI (Computer Assisted Instruction), compact disk (CD) multimedia pembelajaran interaktif, dan bahan ajar berbasis web (web based learning materials).

Bahan ajar memiliki beragam jenis, ada yang cetak maupun noncetak. Bahan ajar cetak yang sering dijumpai antara lain berupa handout, buku, modul, brosur, leaflet, lembar kerja siswa, wallchart, dan foto/gambar (Prastowo, 2011:66).

Bahan ajar noncetak meliputi bahan ajar dengar (audio) seperti kaset, radio, piringan hitam, dan compact disc audio. Bahan ajar pandang dengar (audio visual) seperti video compact disc dan film. Bahan ajar multimedia interaktif seperti CAI (Computer Assisted Instruction), compact disc multimedia pembelajaran interaktif, dan bahan ajar berbasis web (web based learning materials).

\section{Karakteristik dan Kelayakan Bahan Ajar \\ Dalam penyusunan sebuah bahan} ajar tentu harus memperhatikan karakteristik bahan ajar. Karakteristik dalam penyusunan bahan ajar perlu diperhatikan dengan baik. Sama halnya dengan yang diungkapkan Daryanto (2013:9-11) yang mengungkapkan bahwa sebuah bahan ajar bisa dikatakan baik dan menarik apabila terdapat karakteristik sebagai berikut: (1) self instruction, (2) self contained, (3) stand alone, (4) adaptif, dan (5) user friendly.

Menurut BSNP (dalam Muslich, 2010:292-312) bahan ajar yang berkualitas wajib memenuhi empat aspek kelayakan, yaitu: (1) kelayakan isi/materi, (2) kelayakan penyajian, (3) kelayakan bahasa, dan (4) kelayakan kegrafikan.
Dalam hal kelayakan isi/materi, ada tiga indikator yang harus diperhatikan, yaitu (1) kesesuaian uraian materi dengan kompetensi inti dan kompetensi dasar yang terdapat dalam kurikulum mata pelajaran yang bersangkutan, (2) keakuratan materi, (3) materi pendukung pembelajaran.

Dalam hal kelayakan penyajian, ada tiga indikator yang harus diperhatikan, yaitu (1) teknik penyajian, (2) penyajian pembelajaran, dan (3) kelengkapan penyajian. Dalam hal kelayakan bahasa, ada tiga indikator yang harus diperhatikan, yaitu (1) kesesuaian pemakaian bahasa dengan tingkat perkembangan siswa, (2) pemakaian bahasa yang komunikatif, dan (3) pemakaian bahasa memenuhi syarat keruntutan dan keterpaduan alur berpikir. Dalam hal kelayakan kegrafikan, ada tiga indikator yang harus diperhatikan dalam modul, yaitu: (1) ukuran buku, (2) desain kulit buku, (3) desain isi buku.

Dari penjelasan di atas dapat diambil kesimpulan bahwa karakteristik bahan ajar haruslah sesuai dengan kebutuhan peserta didik sehingga bahan ajar harus di susun sesuai dengan karakter penyusunan bahan ajar. Sebuah bahan ajar dapat dikatakan berkualitas dan layak untuk digunakan dapat dinilai berdasarkan tiga aspek, yaitu aspek-aspek yang didasarkan pada standar penilaian bahan ajar oleh Badan Standar Nasional Pendidikan (BSNP).

\section{Pengertian Menulis}

Menulis merupakan salah satu kegiatan yang menghasilkan tulisan. Akan tetapi, bukan hanya sekadar tulisan saja yang dihasilkan dari tulisan. Tarigan (2008:3) mengemukakan bahwa menulis merupakan suatu keterampilan berbahasa yang dipergunakan untuk berkomunikasi secara tidak langsung, tidak secara tatap muka dengan orang lain. Menulis merupakan suatu kegiatan yang produktif dan ekspresif. Pengertian menulis juga 
dikemukakan oleh Dalman (2011:3) yang mengatakan bahwa menulis adalah kegiatan komunikasi berupa penyampaian pesan (informasi) secara tertulis kepada pihak lain dengan menggunakan bahasa tulis sebagai alat atau medianya. Menulis merupakan sebuah proses kreatif menuangkan gagasan dalam bentuk bahasa tulis dalam tujuan, misalnya memberi tahu, meyakinkan atau menghibur.

Berbeda dengan Tarigan (dalam Siddik, 2010:3) yang mengatakan bahwa menulis adalah menurunkan atau melukiskan lambang-lambang grafik yang menggambarkan suatu bahasa yang dipahami oleh seseorang sehingga orang lain dapat membaca lambang-lambang grafik tersebut, kalau mereka memahami bahasa dan gambaran grafik itu. Menulis berarti melahirkan atau mengungkapkan pikiran atau perasaan melalui suatu lambang (tulisan). Berdasarkan uraian yang telah dipaparkan, dapat disimpulkan bahwa menulis merupakan suatu kegiatan seseorang untuk mengungkapkan pendapat, ide, pikiran, atau gagasan melalui media tulisan untuk dapat dibaca oleh orang lain.

\section{Pengertian Cerita Pendek (Cerpen) \\ Cerita pendek merupakan salah} satu jenis karya sastra yang cukup popular dengan singkatan cerpen. Cerpen hanya memuat sebuah penceritaan yang memusat pada satu peristiwa pokok, sedangkan peristiwa itu tentu tidak sendiri, ada peristiwa lain yang sifatnya mendukung peristiwa pokok. Cerpen, sesuai dengan namanya, adalah cerita yang pendek. Akan tetapi, berapa ukuran panjang pendek itu memang tidak ada aturannya, tidak ada satu kesepakatan di antara para pengarang dan para ahli (Nurgiyantoro, 2015:10).

Berdasarkan pendapat di atas, dapat disimpulkan bahwa cerpen merupakan salah satu bentuk karya sastra yang menarik, relatif pendek, yang menceritakan sebagian kecil saja dari kehidupan tokoh. Berdasarkan penjelasan di atas kita dapat menentukan ciri-ciri cerpen. Ciri-ciri tersebut dapat dikemukakan sebagai berikut: (1) cerita pendek merupakan sebuah kisahan pendek yang dibatasi oleh jumlah kata atau halaman; (2) cerita pendek biasanya memusatkan perhatian pada peristiwa, artinya hanya mengangkat beberapa peristiwa dalam kehidupan tidak seluruhnya; (3) cerita pendek mempunyai satu alur; (4) cerita pendek mempunyai satu tema; (5) isi cerita berasal dari kehidupan sehari-hari, biasanya dari pengalaman pribadi atau kehidupan orang lain; (6) penggunaan kata yang mudah dipahami; dan (7) penokohan pada cerpen sangat sederhana, tidak mendalam serta singkat.

\section{Unsur-Unsur Pembangun Cerita Pendek (Cerpen)}

Cerpen merupakan salah satu bentuk karya sastra fiksi yang sifatnya menghibur. Selain itu, dikarenakan cerpen ditampilkan dengan bentuk lebih padat, baik dari jalan cerita, tokoh, sampai setting cerita. Seperti halnya novel, cerpen dibangun atas unsur-unsur yang saling erat berkaitan. Kepaduan antarunsur pembangun akan melahirkan cerita yang bagus. Unsur-unsur pembangun tersebut di antaranya adalah tema, alur atau plot, tokoh, latar (setting), sudut pandang (point of view), dan gaya (style).

\section{Pengertian Media}

Kata media berasal dari bahasa Latin medius yang secara harfiah berarti "tengah", "perantara", atau "pengantar". Dalam bahasa Arab, media adalah perantara atau pengantar pesan dari pengirim kepada penerima pesan. Gerlach dan Ely (dalam Arsyad, 2013:3) mengatakan bahwa media apabila dipahami secara garis besar adalah manusia, materi, atau kejadian yang 
membangun kondisi yang membuat siswa mampu memperoleh pengetahuan, keterampilan, atau sikap Dalam pengertian ini guru, buku teks, dan lingkungan sekolah merupakan media. Secara lebih khusus, pengertian media dalam proses pembelajaran cenderung diartikan sebagai alat-alat grafis, fotografis, atau elektronis untuk menangkap, memproses, dan menyusun kembali informasi visual atau verbal.

Sementara menurut Arsyad (2013:4) media adalah semua bentuk perantara yang digunakan oleh manusia untuk menyampaikan atau menyebar ide, gagasan atau pendapat sehingga ide, gagasan atau pendapat yang dikemukakan itu sampai kepada penerima yang dituju. Suparman (dalam Asyhar 2012:4) mengemukakan bahwa media merupakan alat yang digunakan untuk menyalurkan pesan dan informasi dari pengirim pesan kepada penerima pesan.

Dari beberapa penjelasan di atas, dapat disimpulkan bahwa media adalah alat untuk menyampaikan informasi kepada penerima dan segala sesuatu yang dapat digunakan untuk menyalurkan pesan dari pengirim ke penerima sehingga dapat merangsang pikiran, perasaan, perhatian agar terjadi komunikasi yang efektif dan efisien.

\section{Macam-Macam Media}

Macam-macam media menurut Asyhar (2012:44) media dapat dikelompokkan menjadi 4 macam yaitu: (1) media visual, (2) media audio, (3) media audio-visual, dan (4) multimedia. Berdasarkan perkembangan teknologi, menurut Arsyad (2013:31) mengatakan bahwa media dapat dikelompokkan ke dalam empat kelompok yaitu: (1) media hasil teknologi cetak, (2) media hasil teknologi audiovisual, (3) media hasil teknologi yang berdasarkan komputer, dan (4) media hasil gabungan teknologi cetak dan komputer.

Berdasarkan beberapa pandangan di atas mengenai macam-macam media pengajaran maka dapat disimpulkan bahwa media dapat dikategorikan menjadi empat jenis media yaitu media audio, media visual, media audio visual dan multimedia.

\section{Pengertian Storyboard}

Papan cerita (storyboard) adalah salah satu cara alternatif untuk mensketsakan kalimat penuh sebagai alat perencanaan. Papan cerita menggabungkan alat bantu narasi dan visualisasi pada selembar kertas sehingga naskah dan visual terkoordinasi. Storyboard ini membantu kita untuk merancang sebuah cerita seperti halnya membuat gambaran kasar sebelum kita membuat objek aslinya. Menurut Rohani (2007:21), papan cerita (storyboard) adalah sebagai media yang merupakan reproduksi bentuk asli dalam dimensi, yang berupa foto atau lukisan. Hal yang sama juga dikemukakan oleh Arsyad Azhar (2013:89) bahwa bentuk visual bisa berupa gambar representasi seperti gambar, lukisan atau foto yang menunjukkan tampaknya suatu benda sehingga dapat memperlancar pemahaman terhadap informasi yang telah diyakinkan.

Menurut Wiesendanger (2001:161), storyboard merupakan aktivitas sebelum menulis yang menekankan pada elaborasi (penjelasan yang detail) prediksi atau perkiraan, penumbuhan gagasan, dan pengurutan. Hal ini digunakan untuk memotivasi siswa untuk mengembangkan kemampuan diri dalam menulis yang diawali dengan membuat kerangka karangan yang berupa gambar dan kemudian dikembangkan menjadi sebuah paragraf. Storyboard ini melibatkan membaca, menulis dan mengilustrasikan. Hal ini efektif karena memotivasi penulis dan pembaca pemula. Storyboard menurut Indrawaty (2011) adalah area berseri dari sebuah gambar sketsa yang digunakan sebagai alat perencanaan untuk menunjukkan secara visual bagaimana aksi dari sebuah cerita berlangsung. Storyboard 
merupakan naskah yang dituangkan dalam bentuk gambar atau sketsa yang berguna untuk lebih memudahkan kameramen dalam pengambilan gambar. Storyboard secara harfiah berarti dasar cerita, storyboard adalah penjelasan bagaimana cara seseorang akan membuat suatu proyek. Jika diumpamakan sebagai pembuatan film, maka bisa dikatakan bahwa storyboard adalah skenario film tersebut. Berdasarkan pengertianpengertian tersebut dapat disimpulkan bahwa storyboard adalah sketsa gambar yang disusun berurutan sesuai dengan ide cerita, dengan storyboard kita dapat menyampaikan ide cerita kita kepada orang lain dengan lebih mudah karena kita dapat menggiring khayalan seseorang mengikuti gambar-gambar tersebut sehingga menghasilkan sebuah cerita yang runtut.

\section{Media Storyboard dan Penera- pannya dalam Pembelajaran}

Media storyboard digunakan pada saat kegiatan sebelum menulis yang menekankan pada elaborasi (penjelasan yang detail), prediksi atau perkiraan, penumbuhan gagasan dan pengurutan. Hal ini digunakan untuk memotivasi siswa untuk mengembangkan kemampuan diri dalam menulis yang diawali dengan membuat kerangka karangan berupa gambar dan kemudian dikembangkan menjadi sebuah paragraf.

Media storyboard ini nantinya diterapkan dalam pembelajaran menulis cerpen. Media ini cocok untuk pembelajaran menulis cerpen karena dalam media ini menekankan pada elaborasi, prediksi atau perkiraan, penumbuhan gagasan, dan pengurutan. Media ini diawali dengan membuat beberapa ilustrasi gambar yang kemudian setiap ilustrasi gambar tersebut dikembangkan menjadi sebuah paragraf sehingga menjadi sebuah cerita yang utuh. Media storyboard ini melibatkan membaca, menulis, dan mengilustrasikan. Hal ini efektif karena memotivasi penulis pemula. Langkah yang digunakan dalam media storyboard menurut Wiesendanger (2010:165) adalah: (1) guru memberikan selembar kertas yang telah dibagi menjadi 6-8 kotak/bagian, (2) siswa mencari gagasan tentang ide-ide cerita dan menggambar peristiwa awal dan akhir pada bagian pertama dan terakhir dari kertas tersebut, (3) siswa mengisi bagianbagian yang tersisa dalam urutan yang sesuai ketika mereka mengembangkan ide-ide cerita mereka, (4) siswa memeriksa urutannya, lalu mengoreksi draf pertama yang mereka buat, (5) siswa menambahkan kata-kata pada gambar mereka dan membuat kerangka finalnya atau menyelesaikan karyanya, (6) siswa diperbolehkan untuk memajang karyanya tersebut atau memublikasikannya, dan (7) siswa menyampaikan cerita mereka kepada teman-teman yang lain.

Keunggulan media storyboard adalah penggunaan gambar dalam proses menulis cerpen, berbeda dengan kerangka karangan yang umum digunakan. Menggambar dapat menambah kreativitas siswa dalam mengembangkan ide. Karena gambar merupakan perangkat pembelajaran yang sangat menarik minat belajar siswa. Selain itu, media storyboard juga dapat memudahkan siswa dalam menjelaskan cerita tanpa keluar dari ide utamanya.

\section{METODE PENELITIAN}

Penelitian ini merupakan penelitian dan pengembangan atau Research \& Development (R\&D). Penelitian dan pengembangan merupakan metode penelitian yang digunakan untuk mengembangkan atau memvalidasi produk-produk yang digunakan dalam pendidikan dan pembelajaran. Penelitian ini mengembangkan produk berupa bahan ajar menulis cerpen dengan media storyboard pada siswa kelas X SMA. Prosedur pengembangan penelitian ini berdasarkan sepuluh langkah menurut 
Borg dan Gall yang dimodifikasi sesuai dengan konteks dan kebutuhan pengembangan bahan ajar menulis cerpen dengan media storyboard pada siswa kelas $\mathrm{X}$ SMA yang mengacu pada masingmasing langkah penelitian dan pengembangan. Sepuluh langkah penelitian dan pengembangan (menurut Borg dan Gall sebagai berikut: analisis kebutuhan, perencanaan, pengembangan produk awal, revisi produk awal, uji coba produk, revisi produk, uji coba lapangan utama (kelompok kecil), revisi produk, uji lapangan operasional (kelompok besar), revisi produk akhir, dan diseminasi dan implementasi produk.

\section{HASIL DAN PEMBAHASAN}

\section{Hasil Uji Coba Produk}

Uji Coba ahli atau validasi dilakukan dengan tujuan untuk menguji kelayakan dan keefektifan bahan ajar yang dibuat sebelum diujicobakan kepada siswa, serta untuk mengetahui setiap detail kekurangan atau kelemahan produk. Hasil uji validasi ahli materi yakni ibu Dra. Sri Rahayu, M. Pd diperoleh hasil persentase 93\% yang artinya dari hasil penilaian produk menurut ahli materi bahwa produk bahan ajar menulis cerpen dengan media storyboard sangat baik/sangat layak digunakan dalam proses pembelajaran. Berdasarkan hasil validasi ahli media oleh Bapak Effendi Limbong, S. Pd., M. Ed. Diperoleh hasil persentase $93 \%$ yang termasuk pada kategori sangat baik. Hal ini berarti produk bahan ajar menulis cerpen dengan media storyboard sangat baik/sangat layak diproduksi untuk digunakan dalam proses pembelajaran. Berdasarkan penilaian yang telah dilakukan oleh pengamat mengenai perencanaan pembelajaran yang telah dilakukan peneliti telah diperoleh skor 93\% dengan kategori sangat baik. Penilaian yang telah dilakukan oleh pengamat mengenai pelaksanaan pembelajaran yang telah dilakukan peneliti memperoleh skor $89 \%$ dengan kategori baik.

Untuk mendapatkan produk bahan ajar menulis cerpen dengan media storyboard yang baik, maka perlu diadakan uji coba produk pada kelompok kecil yang ditujukan kepada siswa kelas X sebanyak 10 orang yang dipilih secara acak dari 6 kelas. Dari hasil uji coba tes awal ini diketahui bahwa dari 10 siswa yang mengikuti uji coba hanya 4 siswa yang mampu memperoleh nilai mencapai Kriteria Ketuntasan Minimal (KKM) 72, sedangkan 6 siswa lainnya masih mendapatkan nilai di bawah KKM. Setelah dilakukan tes awal ini, peneliti melakukan kegiatan uji coba produk pada kelompok kecil. Hasil yang diperoleh adalah 10 siswa mampu memperoleh nilai di atas KKM. Secara rinci perolehan nilai siswa dapat diketahui bahwa terjadi peningkatan nilai dari hasil belajar tes awal dan tes akhir pada uji coba kelompok kecil yakni dari capaian nilai rata-rata tes awal adalah 69 meningkat menjadi 82. Hal ini menunjukkan bahwa penggunaan bahan ajar menulis cerpen dengan media storyboard dapat meningkatkan kemampuan menulis cerpen siswa.

Berdasarkan data hasil uji coba kelompok kecil dan uji lapangan operasional yang telah dilakukan di kelas $\mathrm{X}$ SMA Negeri 8 Balikpapan dengan merujuk pada kriteria keefektifan dalam penelitian ini, dapat diketahui bahwa bahan ajar menulis cerpen dengan media storyboard dapat meningkatkan hasil belajar siswa. Hal ini terlihat pada hasil uji coba kelompok kecil diperoleh nilai rata-rata 69 pada tes awal dan 83 pada tes akhir. Selanjutnya dilakukan uji lapangan operasional (kelompok besar) diperoleh nilai rata-rata 70 pada tes awal dan tes akhir meningkat menjadi 82. Dari perolehan nilai tersebut dapat dibuktikan bahwa hasil belajar siswa dapat dikatakan tuntas karena nilai masingmasing siswa telah mencapai KKM, yakni 72.

\section{Pembahasan}

Pembahasan ini diawali pada siswa kelas X SMA Negeri 8 Balikpapan semester 
genap yang menyukai bahan ajar menulis cerpen dengan media storyboard di dalamnya. Bahan ajar tersebut banyak menarik perhatian siswa yang ada di sekolah tersebut. Hal ini terlihat dari antusiasnya para siswa ketika membuka lembar demi lembar bahan ajar yang berisikan materi menulis cerpen dengan media storyboard. Fenomena ini terjadi disebabkan banyak faktor dan salah satunya adalah buku teks atau buku pelajaran yang ada di sekolah tersebut tidak mencantumkan materi menulis cerpen dengan media storyboard seperti bahan ajar yang disusun oleh peneliti. Bahan ajar ini dirancang dengan memperhatikan materimateri ajar yang sesuai dan relevan dengan menulis cerpen.

Menurut Prastowo (2011:16) bahan ajar adalah seperangkat materi yang sistematis, baik tertulis maupun tidak tertulis sehingga tercipta lingkungan atau suasana yang memungkinkan peserta didik untuk belajar Pandangan tersebut dipahami bahwa materi di dalam bahan ajar tentunya harus memudahkan siswa sehingga siswa tidak mengalami kesulitan dalam proses pembelajaran.

Supaya siswa dapat menghasilkan tulisan cerpen yang baik, maka guru perlu adanya menggunakan teknik dan media sebagai penyampaian materi dalam pembelajaran. Media pembelajaran adalah salah satu unsur yang mempengaruhi keberhasilan pembelajaran. Hal ini dapat mendorong siswa supaya tertarik dan termotivasi untuk menulis cerpen. Selain itu, media tersebut dapat membantu memudahkan siswa dalam memahami pembelajaran menulis cerpen. Salah satu pengembangan media pembelajaran adalah media storyboard. Media storyboard dianggap sangat efektif dalam pembelajaran menulis cerpen di Sekolah Menengah Atas. Media storyboard dalam pembelajaran menulis cerpen merupakan salah satu media yang cocok guna membantu siswa dalam menulis cerpen karena dengan media storyboard siswa akan menjadi lebih muda dalam mengembangkan cerita atau ide secara runtut berdasarkan urutan waktu ke waktu atau kronologi.

Dengan adanya pengembangan bahan ajar menulis cerpen dengan media storyboard siswa akan lebih tertarik untuk menulis cerpen. Karena dengan media storyboard siswa dapat mengeluarkan ideide kreatif, berimajinasi yang dituangkan dalam bentuk visual atau gambar tentunya hal ini sangat menarik. Menulis cerpen pada umumnya hanya dengan tulisan saja sehingga siswa merasa bosan karena mereka merasakan kesulitan dalam menuliskan ide-ide ke dalam cerpen. Namun berbeda dengan media storyboard ini dapat memotivasi siswa untuk mengembangkan kemampuan menulis cerpen. Media storyboard ini cocok untuk pembelajaran menulis cerpen karena dalam media ini menekankan pada elaborasi, prediksi atau perkiraan, penumbuhan gagasan, dan pengurutan. Media storyboard ini diawali dengan membuat beberapa ilustrasi gambar yang kemudian setiap ilustrasi gambar tersebut dikembangkan menjadi sebuah paragraf sehingga menjadi sebuah cerita yang utuh.

Produk pengembangan bahan ajar menulis cerpen dengan media storyboard ini memiliki beberapa keunggulan. Pertama, keunggulan dari bahan ajar menulis cerpen dengan media storyboard ini adalah penggunaan gambar, lukisan atau foto yang menunjukkan tampaknya suatu benda sehingga dapat memperlancar pemahaman dalam menulis cerpen. Kedua karena storyboard itu adalah menggabungkan alat bantu narasi dan visualisasi pada selembar kertas maka naskah dan visual terkoordinasi. Ketiga, produk pengembangan bahan ajar menulis cerpen dengan media storyboard ini dapat membantu guru dan siswa dalam proses pembelajaran menulis cerpen.. Kekurangan dari produk bahan ajar ini adalah produk ini hanya dibuat berdasarkan analisis kebutuhan di SMA 
Negeri 8 Balikpapan. Jadi, untuk penerapannya di sekolah lain masih perlu penyesuaian dengan analisis kebutuhan guru bahasa Indonesia di sekolah tersebut.

Efektivitas pembelajaran merupakan suatu ukuran yang tercapainya tingkat keberhasilan dari suatu proses pembelajaran. Kriteria keefektifan dalam penelitian ini mengacu pada: (1) ketercapaian hasil belajar dapat dikatakan tuntas apabila sekurang-kurangnya 75\% dari jumlah siswa telah mencapai Kriteria Ketuntasan Minimal (KKM) yang ditetapkan yaitu 72 ; (2) pengembangan dan penggunaan bahan ajar menulis cerpen dengan media storyboard dikatakan efektif jika meningkatkan hasil belajar siswa yang ditunjukkan oleh peningkatan prestasi belajar siswa; (3) ketercapaian perencanaan dan pelaksanaan pembelajaran yaitu pencapaian waktu ideal yang digunakan untuk melakukan setiap kegiatan yang termuat dalam Rencana Pelaksanaan Pembelajaran (RPP).

Data efektivitas pembelajaran tersebut sejalan dengan pendapat Dunne (1996:12) yang mengatakan bahwa efektivitas proses pembelajaran berarti tingkat keberhasilan guru dalam mengajar kelompok siswa tertentu dengan menggunakan metode tertentu untuk mencapai tujuan instruksional tertentu. Dalam penelitian ini, peneliti mengembangkan satu bahan ajar yakni bahan ajar menulis cerpen dengan media storyboard dengan tujuan memudahkan siswa dalam mempelajari materi menulis cerpen. Dunne (1996:12) berpendapat bahwa efektivitas pembelajaran memiliki dua karakteristik. Karakteristik pertama adalah memudahkan murid belajar, sesuatu yang bermanfaat seperti fakta, keterampilan, nilai, konsep atau sesuatu hasil belajar yang diinginkan. Kedua, bahwa keterampilan diakui oleh mereka yang berkompeten menilai, seperti guru, pengawas, tutor atau murid sendiri. Bahan ajar yang telah dikembangkan sebagai bahan ajar yang telah memenuhi kriteria tersebut yakni memudahkan siswa belajar.

Berkaitan dengan uraian di atas, bahwa efektivitas pembelajaran adalah tingkat keberhasilan yang dapat dicapai dari suatu metode pembelajaran tertentu sesuai dengan tujuan pembelajaran yang telah direncanakan. Dan ini dapat juga diartikan bahwa suatu bahan ajar dapat dikatakan efektif ketika memenuhi kriteria, mencapai tujuan, di antaranya mampu memberikan pengaruh, perubahan atau dapat membawa hasil, pemanfaatan waktu yang ideal, dan kemudahan dalam menggunakan bahan ajar. Ketika kita merumuskan tujuan instruksional, maka efektivitas dapat dilihat dari seberapa jauh tujuan itu tercapai. Semakin banyak tujuan tercapai, maka semakin efektif pula bahan ajar tersebut.

\section{E. PENUTUP}

Penelitian pengembangan bahan ajar menulis cerpen dengan media storyboard telah berhasil dilakukan dengan menghasilkan sebuah buku materi menulis cerpen yang telah digunakan siswa sebagai bahan ajar yang memuat materi menulis cerpen dengan sepuluh langkah yang dibagi menjadi tiga tahap. Tahap I studi pendahuluan yang terdiri atas analisis kebutuhan, pengumpulan data/informasi, kajian pustaka, observasi dan wawancara. Tahap II studi pengembangan yaitu perencanaan, pengembangan produk awal, validasi produk awal, revisi produk awal, uji coba produk, revisi produk, uji coba lapangan utama (kelompok kecil), revisi produk, uji lapangan operasional (kelompok besar), revisi produk akhir. Tahap III yaitu tahap akhir yaitu diseminasi dan implementasi produk. Berdasarkan penilaian yang telah dilakukan oleh pengamat mengenai pengembangan perencanaan pembelajaran (RPP) diperoleh skor rata-rata 92\% dengan kategori sangat baik. Hal ini memberikan gambaran bahwa bahan ajar menulis cerpen dengan media storyboard 
sebagai media dalam kegiatan pembelajaran layak digunakan.

Penilaian yang dilakukan oleh pengamat mengenai pelaksanaan pembelajaran diperoleh skor rata-rata $88 \%$ dengan kategori baik. dan dapat meningkatkan hasil belajar siswa. Berdasarkan hasil tersebut, dapat disimpulkan bahwa bahan ajar menulis cerpen dengan media storyboard baik dan layak digunakan sebagai media dalam pelaksanaan pembelajaran. Bahan ajar menulis cerpen dengan media storyboard efektif digunakan dalam proses pembelajaran karena telah memenuhi kriteria ketercapaian yakni dapat meningkatkan hasil belajar siswa, respon positif siswa terhadap bahan ajar dan berhasilnya keterlaksanaan pembelajaran.

\section{DAFTAR PUSTAKA}

Adnan, B. (2013). Peningkatan Keterampilan Menulis Cerpen Melalui Teknik Papan Cerita (Storyboard) Siswa Kelas X.1 SMA Negeri 1 Minggir, Sleman, Yogyakarta. Skripsi. Program Studi Pendidikan Bahasa dan Sastra Indonesia, FBS, Uniersitas Negeri Yogyakarta.

Aksan, H. (2015). Proses Kreatif Menulis Cerpen. Bandung: Nuansa Cendekia.

Arikunto, S. (2010). Prosedur Penelitian: Suatu Pendekatan Praktik. (Edisi Revisi). Jakarta: Rineka Cipta.

Arikunto, S. (2012). Dasar-Dasar Evaluasi Pendidikan. Jakarta: Bumi Aksara.

Arsyad, A. (2013). Media Pembelajaran. Jakarta: Raja Grafindo Persada.

Asyhar, R. (2012). Kreatif Mengembangkan Media Pembelajaran. Jakarta: Referensi.

Borg \& Gall. (1983). Educational Research: An Introduction. New York and London: Longman.
Dalman. (2011). Keterampilan Menulis. Jakarta: PT Raja Grafindo Persada.

Darmiatun, S. (2013). Menyusun Modul. Yogyakarta: Gaya Media.

Daryanto. (2013). Menyusun Baban Ajar Modul untuk Persiapan Guru dalam Mengajar. Yogyakarta: Gava Media.

Departemen Pendidikan Nasional. (2003). Pedoman Penulisan Modul. Jakarta: Direktorat Pendidikan Menengah Kejuruan Direktorat Jenderal Pendidikan Dasar dan Menengah.

Emsir. (2007). Metodologi Penelitian Pendidikan Kuantitatif dan Kualitatif. Jakarta: PT Raja Grafindo Persada.

Hamdani. (2010). Strategi Belajar Mengajar. Bandung: Pustaka Setia

Ibrahim. (2015). Metode Penelitian Kualitatif. Bandung: Alfabeta.

Kastiyawan, M. A., Hudiyono, Y., \& Ahmad, M. R. (2017). Pengembangan Media Levidio Storyboard dalam Pembelajaran Menulis Teks Ulasan Film/Drama pada Siswa Kelas XI SMK. CaLLs Journal of Culture, Arts, Literature, and Linguistics), 3(1), 15-30. doi:http://dx.doi.org/10.30872/cal ls.v3i1.774

Kementerian Pendidikan dan Kebudayaan Republik Indonesia. (2014). Bahasa Indonesia Ekspresi Diri dan Akademik. Jakarta: Pusat Kurikulum dan Perbukuan Balitbang Kemendikbud.

Kodir, A. (2011). Strategi Belajar Mengajar. Bandung: Pustaka Setia.

Lestari, I. (2013). Pengembangan Bahan Ajar Berbasis: Sesuai dengan Kurikulum Satuan Pendidikan. Padang: Akademia Permata.

Muryanto, K. (2007). Aku Pandai Menulis Cerpen. Yogyakarta: Citra Aji 
Parama.

Nurgiyantoro, B. (2012). Teori Pengkajian Fiksi. Yogyakarta: Gadjah Mada University Press.

Nurgiyantoro, B. (2015). Teori Pengkajian Fiksi. Yogyakarta: Gadjah Mada University Press.

Prastowo, A. (2011). Panduan Kreatif Membuat Bahan Ajar Inovatif. Yogyakarta: Diva Press.

Rokhmansyah, A. (2014). Studi dan Pengkajian Sastra. Yogyakarta: Graha Ilmu.

Sayuti, S. A. (2000). Berkenalan dengan Prosa Fiksi. Yogyakarta: Gama Media.

Setyosari, P. (2015). Metode Penelitian Pendidikan \& Pengembangan. Malang: Prenadamedia.

Siddik, M. (2010). Dasar-dasar Menulis dengan Penerapannya. Malang: Tunggal Mandiri.

Sugiarto, E. (2014). Mahir Menulis Cerpen. Yogyakarta: Suaka Media.

Sugiyono. (2011). Metode Penelitian Kombinasi (Mixed Methods). Bandung: Alfabeta.

Sugiyono. (2015a). Metode Penelitian Kuantitatif, Kualiatif, dan R\&D.
Bandung: Alfabeta.

Sugiyono. (2015b). Metode Penelitian \& Pengembangan Research and Development. Bandung: Alfabeta.

Sugiyono. (2015c). Metode Penelitian Pendidikan: Pendekatan Kuantitatif, Kualitatif, dan R※D. Bandung: Alfebeta.

Sukmadinata, N. S. (2009). Metode Penelitian Pendidikan. Bandung: PT Rosda Karya.

Sumardjo, J. (1997). Catatan Kecil tentang Menulis Cerpen. Yogyakarta: Pustaka Pelajar.

Tarigan, H. G. (1985). Pengajaran Gaya Bahasa. Bandung: Angkasa.

Tarigan, H. G. (2008). Menulis sebagai Suatu Keterampilan Berbahasa. (Edisi Revisi). Bandung: Angkasa.

Wiesendanger, K. D. (2001). Strategies for Literacy Education. Ohio: Merill Prentice Hall.

Yuliastanti. (2013). Pengembangan Bahan Ajar Membaca Sastra Berbasis Pendekatan Kontekstual pada Siswa Kelas VIII SMP Kota Yogyakarta. Skripsi. Program Studi Pendidikan Bahasa dan Sastra Indonesia, FBS Universitas Negeri Yogyakarta. 